Journal of Health Policy and Management (2018), 3(1): 56-62

https://doi.org/10.26911/thejhpm.2018.03.01.08

\title{
Does Accreditation Status Affect Job Performance of the Electronic Medical Record Clerks at Community Health Center?
}

\author{
Harinto Nur Seha',2), Didik Tamtomo3), Endang Sutisna Sulaeman4) \\ ${ }^{1)}$ Medical Record and Health Information, School of Health Polytechnics \\ Permata Indonesia, Yogyakarta \\ 2)Masters Program in Public Health, Universitas Sebelas Maret \\ 3)Faculty of Medicine, Universitas Sebelas Maret \\ 4)Department of Public Health, Faculty of Medicine, Universitas Sebelas Maret
}

\begin{abstract}
Background: Primary care doctors and other staff working in primary care require comprehensive and accurate data on patients at the point-of-care if they are to provide high quality health services to their patients. Electronic patient records are an effective method of achieving this objective, by dispensing with the need to use difficult to access, and often illegible, paper-based records. This study aimed to analyze the effect of accreditation status on job performance of the electronic medical record clerks at community health center.

Subjects and Method: This was an analytic observational study with a cross-sectional design. The study conducted for 25 puskesmas (community health centers), in Yogyakarta, from March to June 2018. A sample of 200 patient medical records was selected by simple random sampling. The dependent variables were completeness and accuracy of medical record. The independent variables were tenure and multi task as level 1 in the multilevel model (MLM). Accreditation status of puskesmas was taken as level 2 in the MLM. The data were collected by questionnaire and analyzed by MLM.

Result: Longer tenure $(b=1.03 ; 95 \% \mathrm{CI}=0.30$ to $1.77 ; \mathrm{p}=0.006)$ and single task occupation $(\mathrm{b}=$ 4.21; $95 \% \mathrm{CI}=6.23$ to $2.20 ; \mathrm{p}<0.001$ )were positively associated with completeness of electronic medical record. Likewise, longer tenure $(b=0.54 ; 95 \% \mathrm{CI}=0.079$ to $1.01 ; \mathrm{p}=0.022)$ and single task occupation $(b=2.14 ; 95 \% \mathrm{CI}=3.42$ to $0.87 ; \mathrm{p}=0.001)$ were positively associated with accuracy of medical record medical record. Accreditation status of puskesmas showed negligible contextual effect on completeness $(\mathrm{ICC}=0.36 \%)$ and accuracy $(\mathrm{ICC}=1.17 \%)$ of the electronic medical record.

Conclusion: Longer tenure and single task occupation are positively associated with completeness and accuracy of medical record. Accreditation status of puskesmas shows negligible contextual effect on completeness and accuracy of the electronic medical record.
\end{abstract}

Keywords: completeness, accuracy, tenure, occupation, accreditation status, community health center, electronic medical record

Correspondence:

Harinto Nur Seha. Medical Record and Health Information, School of Health Polytechnics Permata Indonesia, Yogyakarta. Email: harinto_ns@permataindonesia.ac.id. Mobile: +62 85749724513

\begin{tabular}{l}
\hline BACKGROUND \\
\hline Indonesia is one of the "fast-track \\
countries" in the case of the spread of HIV \\
(World Health Organization, 2017). The \\
UNAIDS organization, in 2017, reported \\
that only 7800 (13\%) of HIV sufferers \\
received treatment (UNAIDS, 2017). The \\
government's action in tackling this case is
\end{tabular}

by increasing monitoring and evaluation of services provided to patients using SIHA (HIV / AIDS and STI Information System) (Ministry of Health, 2015). SIHA application is a form of integrated recording and reporting based on electronic medical records. An application can be said as qualified if it has complete and accurate 
data (Mathai et al, 2017), so that it can produce output that can be used as a basis for decision making (Nelsonet al, 2017).

Yogyakarta Special Region, in the first quarter of 2017, the number of PLWHA patients in Yogyakarta City is obtained 543 (41.2\%), Sleman Regency 511 (38.7\%), Gunung Kidul 87 (6.5\%), Bantul 111 (8.4\%), and Kulon Progo 23 (1.7\%) (Directorate General of Disease Control and Environmental Health, 2017).

The data is the result of a report sourced from the SIHA application. The quality of all data included in the application depends very much on the accuracy of the medical records (Ministry of Health of the Republic of Indonesia, 2014). Therefore, this study intends to analyze the quality of medical data by looking at the dimensions of completeness and accuracy and looking for factors that influence the dimensions.

\section{SUBJECTS AND METHOD \\ 1. Study design}

This was an analytic observational study with a cross-sectional design. The study was conducted in Yogyakarta, from March to June 2018.

\section{Population and samples}

The source population of this study was an electronic medical record at the DIY Community Health Center which is filled in by medical records officer. The number of samples taken was 200 medical records from 50 officers in 25 health centers. The sample was selected using stratified random sampling technique at the health center level and simple random sampling at the level of individual officers.

\section{Study variables}

The dependent variable was the completeness and accuracy of electronic medical records. The independent variables at level 1 were tenure and occupation, and at level 2 was accreditation status of community health center.

\section{Operational definition of variables}

Completeness was defined as information as the output of the data processing process represents every actual situation (Wang et al., 1996). It has all the understanding needed to describe an entity (Bovee, 2001).

Accuracy was defined as the level at which data correctly describes objects or "real-world" events that are being explained by the value of data stored in the database in accordance with the reality and referring to systematic rules (Batini et al., 2009).

The work period was defined as the result of absorption from various human activities so that it can grow skills that arise automatically in the actions taken by employees in completing the work.

Position was defined as the position that shows the duties, responsibilities, authority, and rights of an employee in the framework of an organizational unit.

The status of accreditation was defined as the result of an assessment given by the accreditation agency to the relevant agencies for the achievement of the predetermined indicators.

\section{Data Analysis}

Univariate analysis was used to see the frequency distribution and the percentage characteristics of subjects. Bivariate analysis was used to study the relationship between completeness and accuracy with independent variables using chi-square test. Then multivariate analysis was conducted by multilevel approach.

\section{Research Ethics}

Research ethics includes informed consent, anonymity, confidentiality and ethical clearance. The ethical clearance in this study was conducted at Dr. Moewardi hospital, Surakarta. 
Journal of Health Policy and Management (2018), 3(1): 56-62

https://doi.org/10.26911/thejhpm.2018.03.01.08

\section{RESULTS}

\section{Univariate Analysis}

Table 1 describes the characteristics of the officers who filled electronic medical records in 25 health centers in the Yogyakarta area. Officers who have a working period of $<2$ years filling in medical record documents for about 96 (48\%), and officers who have a working period $\geq 2$ years filling in 104 medical record documents (52\%). Medical records filled by officers with single positions were 32 (16\%), and medical records that were filled in by officers who held positions concurrently 168 (84\%).

The number of medical record documents from unaccredited health centers is 24 (12\%), puskesmas with basic accreditation is 48 (24\%), middle accreditation puskesmas is 64 (32\%), primary health centers with accreditation is 40 (20\%), and puskesmas with accreditation plenary is 24 (12\%).

The number of medical records filled with incomplete as many as 57 (28.5\%), and the number of complete medical records as many as 143 (71.5\%). The number of medical records that are filled inaccurately is 90 (45\%), and the number of accurate medical records is 110 (55\%).

Table 1. Univariate Analysis

\begin{tabular}{lll}
\hline \multicolumn{1}{c}{ Variable } & n & (\%) \\
\hline Position & & \\
Single & 32 & 16 \\
Double & 168 & 84 \\
Tenure & & \\
$<2$ years & 96 & 48 \\
>=2 years & 104 & 52 \\
Accreditation Status & & \\
Not accredited & 24 & 12 \\
Basic accreditation (Dasar) & 48 & 24 \\
Middle accredited (Madya) & 64 & 32 \\
Main accredited (Utama) & 40 & 20 \\
Full accreditation (Purna) & 24 & 12 \\
Completeness & & \\
Incomplete & 57 & 28,5 \\
Complete & 143 & 71.5 \\
Accuracy & & \\
Inaccurate & 90 & 45 \\
Accurate & 110 & 55 \\
\hline
\end{tabular}

\section{Bivariate Analysis}

Bivariate analysis was done by connecting the independent variables (working period, position, and accreditation status) with the dependent variable of completeness (table 2), and with the dependent variable of accuracy (table 3).

Table 2 shows the results of the calculation of the service period that has an influence on the completeness with the value of hit Odds Ratio (OR) 2.63 and $p$ value $=0.003$ less than 0.05 ; 95\% CI 1,3924,984 . This shows that there is a significant relationship between the working period and the completeness of medical records.

Position has an influence on completeness $(\mathrm{OR}=0.01 ; 95 \% \mathrm{CI}=0.01$ to $0.49 ; \mathrm{p}=$ o.001). This shows that there is a significant relationship between the position and the completeness of the medical record.

The variable of accreditation status does not have an influence on the completeness of the medical record by not finding the Odds Ratio (OR) calculated value and $\mathrm{p}$ $=0.563$ less than 0.05 .

Table 3 shows the results of the calculation of the working period that has an effect on accuracy $(\mathrm{OR}=2.66 ; 95 \% \mathrm{CI}=$ 1.49 to $4.69 ; \mathrm{p}=0.001)$. This shows that there is a significant relationship between the working period and the accuracy of medical records.

Position has an influence on accuracy $(\mathrm{OR}=0.96 ; 95 \% \quad \mathrm{CI}=0.03$ to 0.33 ; $\mathrm{p}<0.001)$. This shows that there is a significant relationship between the position and the accuracy of medical records.

Accreditation status variables do not have an influence on the completeness of the medical record with no finding of Odds Ratio (OR) and $\mathrm{p}=0.849$ less than 0.05.

\section{Multilevel Analysis}

Multilevel analysis was used for hierarchical data. At level 1, there were variables from the character of the officer, namely 
the tenure and occupation. Community health center's accreditation status was included at level 2 because it was hierarchical data with no accreditation categories, basic accreditation, middle accreditation, main accreditation, and plenary accreditation.

Table 4 showed that there was an effect of the employee's tenure on the completeness and accuracy of electronic medical records fulfillment which was statistically significant.

Officers who have a tenure of $\geq 2$ years were more likely to have completeness and accuracy than officers who have a tenure of
$<2$ years $(\mathrm{b}=1.03$; CI $95 \%=0.30$ to $1.77 ; \mathrm{p}=$ 0.006).

There was an effect of occupation on the completeness and accuracy of electronic medical records fulfillment which was statistically significant. Officers who have a single occupation were more likely to fill out electronic medical records in a complete and accurate manner than officers who have multiple occupations $(b=36.96$; CI 95\%<0.01 to 0.95; $\mathrm{p}<0.001$ ).

Variations at the community health center level indicated that there was no contextual effect on the completeness $(\mathrm{ICC}=0.36 \%)$ and accuracy of electronic medical records fulfillment $(\mathrm{ICC}=1.17 \%)$.

Table 2. The Result of Bivariate Analysis on the Determinant of Electronic Medical Record Completeness

\begin{tabular}{|c|c|c|c|c|c|c|c|c|c|}
\hline \multirow[t]{2}{*}{ Independent Variables } & \multicolumn{2}{|c|}{$\begin{array}{c}\text { Not } \\
\text { Complete }\end{array}$} & \multicolumn{2}{|c|}{ Complete } & \multicolumn{2}{|c|}{ Total } & \multirow[t]{2}{*}{$\mathbf{O R}$} & \multirow[t]{2}{*}{$95 \% \mathrm{CI}$} & \multirow[t]{2}{*}{$\mathbf{p}$} \\
\hline & $\mathbf{n}$ & $\%$ & $\mathbf{n}$ & $\%$ & $\mathbf{n}$ & $\%$ & & & \\
\hline Tenure & & & & & & & & 1.39 to & 0.003 \\
\hline$<2$ years & 37 & 38.5 & 59 & 61.5 & 96 & 100 & 2.63 & 4.98 & \\
\hline$\geq 2$ years & 20 & 19.2 & 84 & 80.8 & 104 & 100 & & & \\
\hline Occupation & & & & & & & & 0.01 to & 0.001 \\
\hline Single & 1 & 3.1 & 31 & 96.9 & 32 & 100 & 0.06 & 0.49 & \\
\hline Multiple & 56 & $33 \cdot 3$ & 112 & 66.7 & 168 & 100 & & & \\
\hline Accreditation Status & & & & & & & & & \\
\hline Not Accredited & 9 & 37.5 & 15 & 62.5 & 24 & 100 & - & - & 0.563 \\
\hline Basic Accreditation & 10 & 20.8 & 38 & 79.2 & 48 & 100 & & & \\
\hline Middle Accreditation & 21 & 32.8 & 43 & 67.2 & 64 & 100 & & & \\
\hline Main Accreditation & 11 & 27.5 & 29 & 72.5 & 40 & 100 & & & \\
\hline PlenaryAccreditation & 6 & 25 & 18 & 75 & 24 & 100 & & & \\
\hline
\end{tabular}

Table 3. The Result of Bivariate Analysis on the Determinant of Electronic Medical Record Accuracy

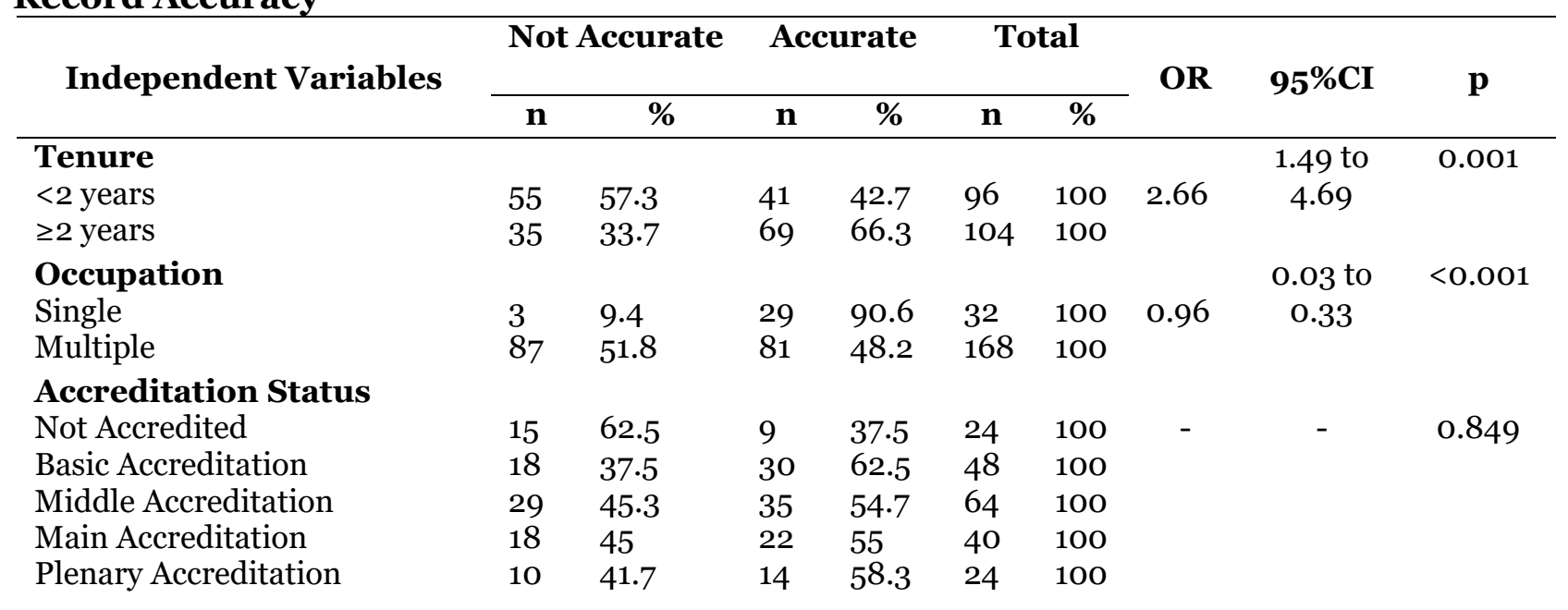


Journal of Health Policy and Management (2018), 3(1): 56-62

https://doi.org/10.26911/thejhpm.2018.03.01.08

Table 4.The Result of Multilevel Analysis

\begin{tabular}{|c|c|c|c|c|}
\hline \multirow{2}{*}{ Variable } & \multirow{2}{*}{ b } & \multicolumn{2}{|c|}{$95 \% \mathrm{CI}$} & \multirow[b]{2}{*}{$\mathbf{p}$} \\
\hline & & Lower Limit & Upper Limit & \\
\hline \multicolumn{5}{|l|}{ Fixed Effect } \\
\hline Tenure (>2 years) & 1.03 & 0.30 & 1.77 & 0.006 \\
\hline Occupation (single) & 4.21 & 6.23 & 2.20 & 0.000 \\
\hline \multicolumn{5}{|l|}{ Random Effect } \\
\hline \multicolumn{5}{|l|}{ Community Health Center } \\
\hline $\begin{array}{l}\text { Var (Constant) } \\
\text { N observation }=200\end{array}$ & 36.96 & $<0.01$ & 0.95 & $<0.001$ \\
\hline Obs per group: & & & & \\
\hline $\min =24$ & $\max =64$ & & & \\
\hline $\begin{array}{l}\text { avg }=40.0 \\
\text { Log likelihood }=-526.10619\end{array}$ & $\mathrm{ICC}=1.17 \%$ & & & \\
\hline
\end{tabular}

\section{DISCUSSION}

1. The effect of tenure on completeness and accuracy

The result of analysis showed that there was an effect of tenure on the completeness and accuracy of electronic medical record fulfillment and it was statistically significant. Officers who have a tenure of $\geq 2$ years were more likely to have completeness and accuracy than officers who have a tenure of $<2$ years $(b=1.03$; CI $95 \%=0.30$ to 1.77 ; $\mathrm{p}=0.006)$. The result of this study was in line with a study by Mailool et al, (2017). Tenure if expressed as work experience, became a good basis for estimating employee's productivity. The longer a person in doing a job, the less likely to resign. Other researchers also expressed the similar thing that the tenure has a positive effect on employee's performance (Sari et al, 2016).

A study by Indar et al. (2013) stated that people with long tenure have adequate experiences related to medical record facility. Based on the results, it can be concluded that there was an effect between the tenure and the completeness and accuracy of electronic medical record fulfillments.

\section{The effect of occupation on completeness and accuracy}

There was an effect of occupation on the completeness and accuracy which was statistically significant. Officers who have a single occupation were more likely to fill out electronic medical records in a complete and accurate manner than officers who have multiple occupations $(b=36.96$; CI 95\%<0.01 to 0.95; $\mathrm{p}<0.001)$. The result of this study was in line with a study by Ulfa et al, (2017) which stated that factor affecting the completeness of medical records was the lack of time in working. Other studies also explained that human resources as predisposing factors also affected the completeness of medical records (Riyantika, 2018).

Another factor that caused incomplete medical records was the limited time to fill in medical records so that the coassistantswere in rush to work on medical records in RSGMP UMY (Ridho et al, 2013). The recording system by medical record officers has not gone well, resulting in a high number of incomplete medical records (Nurhaidah et al, 2016). Based on several studies above, it can be concluded that officers with multiple occupations would have a high workload so that it affected the completeness and accuracy of medical records fulfillment. 


\section{The effect of community health center on completeness and accuracy}

Variations at the community health center level indicated that there was no contextual effect on the completeness and accuracy of electronic medical records fulfillment with ICC values of $0.36 \%$ for completeness and $1.17 \%$ for accuracy. Similar study mentioned that there was no effect between accreditation and the completeness of medical resume sheet (Syarah, 2016). It can be concluded that there was no effect of accreditation status on the completeness and accuracy in medical records fulfillment.

\section{REFERENCES \\ Batini C, Scannapieco M (2006). Data Qua- lity: Concepts, Methodelogies and Techniques, Germany: Springer.}

Bovee CL, John VT (2001). Bussines in Action: Step into the world of opportunity in the 21th century. Prentice Hall. Inc. New Jersey.

Direktorat Jenderal Pengendalian Penyakit dan Penyehatan Lingkungan. (2017). Laporan HIV Triwulan I Tahun 2017. Jakarta.

Indar I, Indar, Naiem MF (2013). Faktor yang Berhubungan dengan Kelengkapan Rekam Medis di RSUD $\mathrm{H}$. Padjonga DG. Ngalle Takalar. Jurnal AKK, 2(2): 10-18.

Kementerian Kesehatan Republik Indonesia (2014). Pedoman pengobatan antiretroviral. Peraturan Meteri Kesehatan Republik Indonesia, Nomor 87 Tahun 2014, 1-121. https://doi.org/10.1017/CBO9781107415324.004.

Mailool CM, Pondaag L, Lolong J (2017). Hubungan Faktor Personal Dengan Kinerja Perawat Pelaksana di Instalasi Rawat Inap RSU Pancaran Kasih GMIM Manado. eJournal Keperawatan, 5(1).
Mathai N, Shiratudin MF, Sohel F (2017). Electronic Health Record Management: Expectations, Issues, and Challenges. Journal of Health \& Medical Informatics, 8(3). https://doi.org/10.4172/2157-7420.1000265.

Nelson GS, Technologies T, Hill C (2017). A Practical Guide to Healthcare Data: Tips, traps, and techniques.

Nurhaidah, Harijanto T, Djauhari T (2016). Faktor-Faktor Penyebab Ketidaklengkapan Pengisian Rekam Medis Rawat Inap di Rumah Sakit Universitas Muhammadiyah Malang Factors Affecting Incomplete Inpatient Medical Record Completion at Muhammadiyah University Hospital Malang. Jurnal Kedokteran Brawijaya, 29(3), 258-264.

Ridho KM, Rosa EM, Suparniati E (2013). Analisis Faktor - Faktor yang Mempengaruhi Kepatuhan Pengisian Rekam Medis di Rumah Sakit Gigi dan Mulut Pendidikan UMY. Jurnal Medicoeticolegal Dan Manajemen Rumah Sakit, 2(2): 1-18.

Riyantika D (2018). Analisis Faktor-Faktor Penyebab Ketidaklengkapan Pengisian Lembar Resume Medis Pasien Rawat Inap, 7(1): 69-73.

Sari RP, Satrio B (2016). Reny Permata Sari Budhi Satrio Sekolah Tinggi Ilmu Ekonomi Indonesia (STIESIA) Surabaya. Jurnal Ilmu Dan Riset Manajemen.

Syarah (2016). Pengaruh Akreditasi Terhadap Kelengkapan Pengisian Resume Pasien Rawat Inap di RS PKU Muhammadiyah Yogyakarta Unit I.

Ulfa SN, Widjaya L (2017). Faktor-Faktor Yang Mempengaruhi Kelengkapan Diagram Fishbone Di Rumah Sakit Pertamina Jaya. Jurnal INOHIM, 5 .

UNAIDS (2017). UNAIDS Data 2017. Joint United Nations Programme on HIV/ 
Journal of Health Policy and Management (2018), 3(1): 56-62

https://doi.org/10.26911/thejhpm.2018.03.01.08

AIDS. https://doi.org/978-92-9173-945-5.

Wang RY, Strong DM (1996). Beyond Accuracy: What DataQuality Means to Data Consumers. Journal of Management Information System, 12(4):5-34. World Health Organisation (2017). Treat
All: Policy Adoption and Implementation Status in Countries Hiv Treatment and Care, (November 2017). Retrieved from http://apps.who.int/iris/bitstream/10665/259532/1/WH O-HIV-2017.58-eng.pdf?ua=1\%oA 